\title{
Research in language didactics: a model for the evaluation of oral discursive competence in secondary education
}

\author{
M. ${ }^{a}$ Pilar Núñez Delgado \\ Eduardo Fernández de Haro \\ ANTONio Romero López \\ Universidad de Granada \\ Facultad de Ciencias de la Educación
}

Received: 4 June 2007 / Accepted: 28 September 2007

ISSN: $1697-7467$

\begin{abstract}
Research concerning oral language teaching is one of the most unattended fields in linguistic education, both in general terms as well as specifically in Secondary education. This paper tries to take one step towards improving this state of affairs. For this purpose, we create a model for the development of oral discursive competence and we test it in a secondary education course. The pattern of results indicates improvement in the students' oral discursive competence during the development of such a model. This procedure leads to a systematic relation between theory and practice that places us in the scientific scope of the Language Didactics field, a field to which we would like to contribute in an educational and scientific way.
\end{abstract}

Key words: Language didactics, oral discursive competence, secondary education.

RESUMEN: La investigación sobre la enseñanza de la lengua oral en general, y en la etapa secundaria en particular, es uno de los campos hasta ahora más desatendidos dentro del ámbito de la educación lingüística. El trabajo que aquí se presenta constituye un intento de mejorar este estado de cosas por medio de la elaboración de un modelo para el desarrollo de la competencia discursiva oral al que ha seguido la confección de un programa específico que se ha aplicado en un curso de ESO. Este modo de proceder configura una relación sistémica entre la teoría y la práctica educativa que nos sitúa en el ámbito científico de la Didáctica de la Lengua, una disciplina con objeto y métodos propios a cuya consolidación en su doble proyección docente y de investigación, pretendemos contribuir.

Palabras clave: didáctica de la lengua, competencia discursiva oral, educación secundaria.

\section{INTRODUCTION: THEORETICAL BACKGROUND}

The design of oral language learning programs should begin with the elaboration of a theoretical basis of communicative and functional orientation. This theoretical basis should 
then develop the learners' discursive competence and, in a sense, their complete insertion as citizens of the new Europe.

This theoretical assumption has been the starting point in the elaboration of a model for the development of oral discursive competence. Its main foundations are based on the theories of Coseriu (1992), who distinguishes three levels in linguistic competence, corresponding to three types of knowledge:

a) General linguistic level (general linguistic competence) refers to the general principles of thought and knowledge of extralinguistic reality manifested in language. It also refers to the act of speaking reflected in what and how something is and is not said. It is knowledge valid for all languages, what Coseriu calls elocutional knowledge. This knowledge allows us to interpret meanings, accept something as coherent or reject it as incoherent, make sense of a deliberate incongruence, not make explicit what is presupposed, etc. The concepts of coherence and incoherence are related to this knowledge, to which Coseriu assigns two scopes: the logic of discourse and its construction.

The content corresponding to this level is designation, which concerns the reference content, the extralinguistic.

b) Particular language level (particular linguistic competence) corresponds to idiomatic knowledge. It covers the particular rules of a given language, rules that turn a deviation into a mistake in one language but not another. It is equivalent to what is usually referred to as grammar.

With idiomatic knowledge we relate what is correct and incorrect with the different levels of linguistic analysis: phonic, lexical-semantic and morph-syntactic.

The content corresponding to this level is meaning, which consists in the particular organization of the designation in a given language.

c) Discourse level (textual linguistic competence) corresponds to expressive knowledge. In a given language, this knowledge is related to the textual or discursive level, i.e. the faculty of knowing how to apply appropriate communicative factors according to the situation, interlocutors and topic that shape the communicative act.

The concepts related to this knowledge are adequacy or inadequacy, referring to the object, the situation and the interlocutor of the communicative act.

Coseriu saves the concept sense for the particular content of a text. Sense goes beyond meaning and designation and relates to the attitude of the speaker, his/her intention, verbal expression, etc. Sense is always present, even when we try to be objective while referring to something.

Along with these premises, we need to consider contributions from different disciplines to create a more useful model of discursive competence in the teaching context (Núñez, 2002). We must also consider theories that focus their attention on discourse, on the enunciation process, on the social and interpersonal functioning of signs, and on the activity of the receptor as meaning constructor. Thus, aspects from disciplines such as Text Linguistics (Halliday \& Hassan, 1976; Van Dijk, 1989); Pragmatics (Leech, 1983; Haverkate, 1994); Linguistic Ethnography and Anthropology of Communication (Grice, 1975; Sperber \& Wilson, 1986) have been taken into account. 
With this background in mind, in addition to additional premises specified below, we propose an initial approach in order to define the different categories and subcategories that form oral discursive competence:

a) Coherence concerns mastery of information processing. It establishes the relevant information to be communicated and its method of communication.

Textual coherence can be interpreted differently according to the bibliography consulted: as a grid of connections, as framework between the parts of a text, or as "absence of contradictions". Regardless of these differences in interpretation, a didactic goal in the classroom needs to be teaching learners to interpret incoherencies and to help themselves with contextual and situational factors.

For this purpose, Coseriu's proposal (1992) is especially useful where text coherence (or incoherence) is to be envisaged in two scopes: the logic of the discourse and its construction. The logic of discourse is understood as speech in accordance with the principles of thought and is therefore common to all languages in the world. Indeed, it is a knowledge whose mastery allows us: a) to accept and express something as coherent or reject it as incoherent; b) to interpret the speaker's voluntary deviation with respect to thought laws; and, c) to make sense of deliberate contradiction. The construction of discourse is envisioned as knowledge common to all languages based on the general understanding of things, by virtue of which there are different ways for the construction to manifest itself. This knowledge allows us: a) to accept or reject what has been said as congruent or incongruent to general understanding about things, i.e., as they usually are; b) to not say, due to understanding of things, what is already known or understood; and, c) to allow interpretation of what appears obviously incongruent.

Concerning coherence from a didactic point of view, we find it useful to bring up the concept of frame coined by Bateson (1994). Frame is the instrument used to define the communicative situation, i.e., the set of operations that characterize our conventional knowledge of the communicative situations. Every text has its own frame according to which meaning and coherence will be attributed; nevertheless the reader can change it at the communicative level. Here, we come across the figure of the reader as an active agent, filling in the gaps present in the text and attributing sense to it. Thus, we believe this task should also be included in a linguistic and literary school education, where receptive abilities have been disregarded.

b) Cohesion refers to the grammatical, lexical and semantic mechanisms through which the information in the text is articulated. These mechanisms include linking words, articles, pronouns, diaphoric substitution (anaphoric and cataphoric), mood structure, predicate time and aspect, or word order.

According to Halliday and Hassan (1976), there is cohesion when the interpretation of a discourse element depends upon the interpretation of another discourse element. Cohesion is therefore a property more related to semantics and lexicon than to text structure. However, De Beaugrande and Dressler (1981) relate cohesion to grammar, especially to syntax, since they understand it as the way in which the components of textual surface connect in a sequence.

From a didactic point of view, it is as relevant to work on cohesion when it refers 
to semantic relations as when it refers to linking words since both are linked. Semantic relations would include introducing and detecting relations of synonymy, antonymy, polysemy, etc. in a text; using paralinguistic mechanisms to reinforce the meaning of a text; introducing exophoric and endophoric deictic elements in a text, etc. On the other hand, linking word practices would include highlighting logic relations of different types in a text and using varied linking words and textual markers depending on the intended meaning being communicated.

c) Adequacy refers to knowledge and mastery of linguistic diversity, i.e., the ability to choose from among all linguistic possibilities the most adequate to the situation, the interlocutor and the topic.

According to Cassany, Luna and Sanz (1994), this property relates to the mastery of linguistic diversity. Coseriu (1992) places it at the discourse level and relates it not only to the situation, but also to the object of discourse and the interlocutor.

d) Correction regulates the application of the rules of the different linguistic subsystems as well as the presentation of the text. Following Coseriu (1992), it is related to idiomatic knowledge, whereas Casany, Luna and Sanz (1994) identify it with grammar, since it is the textual property that regulates the application of the various linguistic subsystems as well as the presentation of the text.

e) The Principle of Cooperation stated by Grice (1975) declares that any purpose or direction of a verbal interaction requires the speaker to participate in a certain way in that interaction. This principle contains four maxims: i) quantity, according to which the contribution needs to contain the exact amount of information in relation to the goals of the exchange; ii) quality, which states that information needs to be true; iii) relation, which requires information to be pertinent; and iv) manner, which seeks brevity and order and avoidance of ambiguity.

Sperber and Wilson (1986) sum up Grice's maxims in a more general principle, pertinence. In a communicative act, this principle implies that the speaker is to be as pertinent as possible according to the situation, so that the receptor gets to interpret what he/she is attempting to say while processing as effortlessly as possible. All maxims would then depend upon the maxim of pertinence or relevance, since this maxim attempts to explain how the cognitive mechanisms of utterance emission and interpretation work: efficiency in communication depends on correct use of our devices to process information, so that we contribute as economically as possible to our cognitive goals.

f) The maxim of politeness (Leech, 1983) is another basic principle regulating communicative exchanges, especially oral ones. Studies on politeness start with the notions of image and territory, with mechanisms existing in all cultures to avoid the risk of invading someone's territory or to impede yours from being invaded. This principle entails that social and cultural restrictions operate upon linguistic repertoire choice.

Haverkate (1994) deepened the study of verbal politeness. A phrase is polite when the speaker does not violate the rights or obligations at the time of utterance. Politeness rules determine the style of the verbal interaction but do not affect the propositional content of what is communicated. Thus, expressing politeness is not an autonomous act, but a sub-act of the speech act. According to Haverkate, acquisition of politeness rules happens at a relatively late age compared to the phonological and syntactic 
system. The reason for this is that from a rational point of view verbal politeness rules go against clarity and communicative efficiency.

Brown and Levinson (1987) propose three types of politeness strategies: positive, negative, and hidden. Each of them takes shape in particular forms in each cultural group and constitute an important part of communicative competence.

\section{Methodology}

\subsection{Aim of the study}

The objective of the present research is twofold. First of all, to fill a void in the panorama of oral language didactic studies which thus far has been superficially approached in the literature. Secondly, to empirically support the fact that the work on oral language within the area of Castilian language and literature in the Obligatory Secondary School Education of Spain (Educación Segundaria Obligatoria, or ESO) with a specific didactic program contributes to the development of the global discursive competence of the students.

The study is centered on ESO due to the repeated claim that, while primary education considers that students speak well for their age and communicative needs, their arrival at secondary school confirms that their level of oral competence is deficient. We believe it is necessary to take advantage of secondary students' transition to adulthood to offer them the opportunity to take responsibility for and overcome these deficiencies. This is a better approach than lamenting the state in which they arrived at secondary school. There is no need to insist on the cultural, social, and professional importance of possessing a certain mastery of oral expression and comprehension.

This experiment provides evidence for a change which should affect the global conception of the area and the approaches involved in its treatment. Thus, it presupposes an enormous amplification of interest, as much by the past (through the recuperation of valid aspects of the rhetorical language and literature teaching model), as in the present (through the incorporation of elements of the new language sciences).

Theoretically, the conclusions arrived at from a review of bibliographical sources have served to establish a first curricular project proposal in the area of ESO Language and Literature. This proposal is necessarily decontextualized because of its theoretical character, but sufficiently valid as a starting point for the design of the experimental program. The experiment consists of offering methods to students which will allow them to overcome difficulties. These methods will be coherently integrated into the previously established objectives and contents of an ESO course.

Our ultimate goal in this work has been to situate ourselves in the scientific scope of the Language Didactics field. In order to do so, the study concentrates on systematizing the knowledge of linguistic education to assure reflexive practice (in such a fashion that into this conceptual framework, knowledge generated by the practice itself fits as well). Most specifically, it concentrates on the elaboration of proposals of intervention in the classroom starting from certain theoretical principles proven through quasi-experimental designs.

From a holistic perspective, our aim has been to outline a process of didactic transposition. We propose theoretical methods (epistemological, psychological, pedagogical and socio-cultural) 
applicable in the classroom for the teaching and learning of language in general, and the oral skill specifically. All of these proposals are structured in an experimentally validated program.

\subsection{Study hypothesis}

The research hypothesis relates to the subjects' oral discursive competence before, during, and at the end of the development of the Didactic Intervention Program as follows: "Students in second grade of ESO that follow the Didactic Intervention Program for the Development of Oral Discursive Competence enhance their linguistic abilities in spoken language in a significant way during the development of such a program."

\subsection{Experimental design}

A "quasi-experimental" design has been used in this research, therefore inserted into a "quantitative-like" methodology as described by Dendaluce (1994). According to Cronbach (1987), in quasi-experimental designs the aim becomes to establish causality relationships between the independent variable (in our case, the Didactic Intervention Program for the Development of Oral Discursive Competence) and the dependent variables (the improvement of the categories that form such discursive competence). For this purpose, the examined data must be collected under different experimental conditions (e.g., pretest-posttest) without randomly assigning subjects to specific experimental conditions.

\subsection{Participants}

The experimental group consists of twenty-eight students from a single class of a secondyear of ESO at the secondary school of "Sierra Almenara" in Guadairo (Cádiz, Spain). This group represents one of the eight units of ESO at that institution.

\subsection{Dependent variables and measurement instruments}

The dependent variables and their respective subcategories considered in this study constitute the evaluation referent for oral discursive competence. The categories and subcategories included are as follows, where: 5= Very good; $4=$ Good; $3=$ Acceptable; $2=$ Bad; $1=$ Very bad. 


\begin{tabular}{|c|c|c|c|c|c|c|}
\hline \multicolumn{7}{|c|}{ ORAL DISCURSIVE COMPETENCE } \\
\hline Categories & Subcategories & 1 & 2 & 3 & 4 & 5 \\
\hline \multirow[t]{2}{*}{ I. COHERENCE } & $\begin{array}{l}\text { 1. Coherence with reference to } \\
\text { the logic of discourse. }\end{array}$ & & & & & \\
\hline & $\begin{array}{l}\text { 2. Coherence with reference to } \\
\text { the construction of discourse. }\end{array}$ & & & & & \\
\hline \multirow{3}{*}{ II. CORRECTION } & 3. Morphosyntactic correction. & & & & & \\
\hline & 4. Lexico-semantic correction. & & & & & \\
\hline & $\begin{array}{l}\text { 5. Phonetic-phonological } \\
\text { correction. }\end{array}$ & & & & & \\
\hline \multirow[t]{3}{*}{ III. ADEQUACY } & $\begin{array}{l}\text { 6. Adequacy to discourse } \\
\text { object. }\end{array}$ & & & & & \\
\hline & $\begin{array}{l}\text { 7. Adequacy to discourse } \\
\text { situation. }\end{array}$ & & & & & \\
\hline & $\begin{array}{l}\text { 8. Adequacy of discourse to the } \\
\text { interlocutor. }\end{array}$ & & & & & \\
\hline \multirow[t]{2}{*}{ IV. COHESION } & $\begin{array}{l}\text { 9. Discursive cohesion in } \\
\text { semantic relationships. }\end{array}$ & & & & & \\
\hline & $\begin{array}{l}\text { 10. Cohesion through use of } \\
\text { linking words. }\end{array}$ & & & & & \\
\hline \multirow[t]{2}{*}{ V. COOPERATION } & $\begin{array}{l}\text { 11. Pertinence in relation to } \\
\text { cooperation. }\end{array}$ & & & & & \\
\hline & $\begin{array}{l}\text { 12. Clarity according to } \\
\text { cooperation. }\end{array}$ & & & & & \\
\hline VI. POLITENESS & 13. Politeness. & & & & & \\
\hline
\end{tabular}

These dependent variables are defined as follows:

Coherence with reference to the logic of discourse is the presentation of information in a grounded and original way. This would include associations of ideas, use of examples and data to specify general information, establishment of spatial and temporal coordinates in discourse, detection of incoherencies during listening, prediction of possible outcomes, and proposals of approaches, situations or creative and imaginative outcomes.

Coherence with reference to the construction of discourse is the possession of implicit knowledge of the reality that every speaker has, organization of information according to text type (narration, description, exposition, argumentation, and so forth); awareness to avoid repetitions, and the organized introduction of new information without mixing topics or losing unity, while synthesizing previously known information to assure comprehension.

Morphosyntactic correction refers to correct use of grammatical categories, a decrease of grammatical agreement mistakes, use of complete sentences, avoidance of abuse of nominal and impersonal sentences, and use of assorted syntactic structures in relation to text type and topic.

Lexico-semantic correction refers to decreases in the use of clichés, barbarisms and pet words, and unnecessary colloquialisms. It also refers to the use of an acceptably wide lexicon, 
adequate terminology according to the topic of discussion, avoiding generic and imprecise vocabulary, attempts to fill in lexical gaps, the use of synonyms to avoid repeating words, deduction of unknown vocabulary from context and situation, and the comprehension of metaphoric and subliminal meanings.

Phonetic-phonological correction refers to clear vocalization, regulation of voice intensity and elocution speed, adequate distribution of pauses and silences, and the stressing of words and main ideas through intonation.

Adequacy to discourse object refers to adaptation to the spoken object, maintaining the level of depth and specificity in the treatment of the topic throughout its development, and the appropriate use of register-to-text content.

Adequacy to discourse situation refers to right choice of text topic for the situation in which communication is to happen, adjustment of chosen level of formality and situation (formalism/spontaneity), and adequacy of selected linguistic register.

Adequacy of discourse to the interlocutor refers to appropriate choice of topic according to the interests of the interlocutor or interlocutors (age, category, social status, culture, etc). It also includes the adjustment between the selected formality level and the relations maintained with the interlocutor, and between the selected linguistic register and receptor capacity.

Discursive cohesion in semantic relationships refers to the correct use of the most common semantic relationships (synonyms, antonyms, hiperonyms, hyponyms, polysemic words), the inclusion of several types of anaphors (pronouns, ellipsis, synonyms) as well as exophoric and endophoric deictic elements in order to avoid repetitions and assure the receptor's comprehension, and the adequate use of other paralinguistic mechanisms (such as gestures and onomatopoeias) needed to reinforce the text's meaning.

Cohesion through the use of linking-words refers to appearances in the text of varied logic relations (temporal, causal, consecutive, explicative, etc.), adjusted to text type and content; and the use of appropriate linking-words and markers for the pursued type of semantic relationship.

Pertinence in relation to cooperation includes the capacity for interventions in communicative exchanges to have the right quantity of information in relation to the exchange purposes; the pertinence of information to the topic avoiding divagations and arbitrary deviations, and the level of truthfulness of the stated information.

Clarity according to cooperation refers to the capacity of communicative exchanges to be clear and present information in as brief and as balanced a way as possible (combining general and anecdotic, objective and subjective, etc.). It also refers to the ability to present information in an ordered way to facilitate the interlocutor's comprehension.

Politeness is a category that includes preservation of one's role and territory in communicative exchanges without threatening the other's image and space, knowledge of social notions of politeness and verbal formulas (greetings, farewells, treatments, appellatives, etc.) and non-verbal formulas (body attitude, gestures, and glances), and interest for the interlocutor's speech showing agreement or disagreement without brusqueness, adequately applying modesty, tact, and affection conventions. 


\subsection{The independent variable: the Didactic intervention program for the development of oral discursive competence}

The process followed in the application of the Didactic intervention program for the development of oral discursive competence, the independent variable of this investigation, was integrated into the classroom syllabus of the experimental group so that it would pass unnoticed. Thus, it was presented as sporadic activities alongside the rest of the syllabus of this level. The instructional group had a total workload of 4 one-hour-sessions per week over a period of 34 weeks, which turned into 119 one-hour sessions.

\subsection{Procedure}

This research, from which we present some partial studies, was carried out in three stages. During the first stage, before the development of the program, three types of activities were developed: 1) the elaboration of the program (three months); 2) a teacher orientation session (one month); and 3) tests referring to intervening variables and preliminary ones referring to dependent variables completion (two months).

The second stage consisted of the application of the Didactic Intervention Program for the Development of Oral Discursive Competence and the control of its effectiveness. Three phases can be distinguished in this stage: 1) application of the Program during the nine months of the academic year 2) revision and evaluation sessions on the program's development held during the application of the program, with each subject in each of the thematic units also evaluated, and 3) post-tests and control tests of the dependent variables in inter-group study during the last month to check the results.

During the third stage, three types of activities concerning the evaluation of the program's development and its completion were carried out: 1) evaluation of the program from the teacher's perspective and from the experimental group's perspective, 2) elaboration, analysis and discussion of results, and 3) report writing (three months).

\subsection{Statistical study}

The purpose of the statistical study is to evaluate the evolution of the categories and subcategories of oral discursive competence during the program.

We used the BMDP statistical package in this research. The $P 2 D$ application was used to calculate the sample distribution of each variable, and the P3D application was used to test the difference of pretest-posttest means of the dependent variables and the associated $t$-stat (student's T).

\section{RESULTS}

To globally evaluate the group's improvements during the program, we test the differences in means between the first unit (pretest) and the last unit (posttest) of the program. We also show the t-stat. Thus, intra-group differences might be confirmed as a consequence of the program's application in a real-world classroom. 
Table 1: Comparison of group means of the first and last units of the program

\begin{tabular}{|l|l|l|l|l|l|l|l|}
\hline \multicolumn{1}{|c|}{ VARIABLES } & \multicolumn{2}{|c|}{ MEAN RESULT } & \multicolumn{2}{c|}{ t-stat } & \multicolumn{2}{c|}{ CORRELATION } \\
\cline { 2 - 8 } & PRE. & POS. & DIFF. & VALUE & SIGNI. & VALUE & SIGNI. \\
\hline $\begin{array}{l}\text { Coherence referring to } \\
\text { the logic of discourse }\end{array}$ & 3,1786 & 4,3214 &,- 1429 & $-11,53$ & 0,0000 & 0,8193 & 0,0000 \\
\hline $\begin{array}{l}\text { Coherence referring to } \\
\text { the construction of } \\
\text { discourse }\end{array}$ & 3,2500 & 3,7857 &,- 5357 & $-3,38$ & 0,0022 & 0,7305 & 0,0000 \\
\hline $\begin{array}{l}\text { Morphosyntactic } \\
\text { correction }\end{array}$ & 3,1429 & 3,3571 &,- 2143 & $-1,19$ & 0,2463 & 0,6375 & 0,0002 \\
\hline $\begin{array}{l}\text { Lexico-semantic } \\
\text { correction }\end{array}$ & 2,6786 & 3,4643 &,- 7857 & $-4,99$ & 0,0000 & 0,7291 & 0,0000 \\
\hline $\begin{array}{l}\text { Phonetic-phonological } \\
\text { correction }\end{array}$ & 3,1429 & 3,6071 &,- 4643 & $-3,30$ & 0,0027 & 0,7197 & 0,0000 \\
\hline $\begin{array}{l}\text { Adequacy of } \\
\text { discourse object }\end{array}$ & 3,8929 & 4,1071 &,- 2143 & $-1,80$ & 0,0830 & 0,7759 & 0,0000 \\
\hline $\begin{array}{l}\text { Adequacy of } \\
\text { discourse situation }\end{array}$ & 3,8571 & 4,2500 &,- 3929 & $-3,31$ & 0,0027 & 0,7823 & 0,0000 \\
\hline $\begin{array}{l}\text { Adequacy of } \\
\text { discourse of the } \\
\text { interlocutor }\end{array}$ & 3,6071 & 4,1071 &,- 5000 & $-3,00$ & 0,0057 & 0,6311 & 0,0002 \\
\hline $\begin{array}{l}\text { Discursive cohesion } \\
\text { in semantic } \\
\text { relationship }\end{array}$ & 2,5000 & 3,4286 &,- 9286 & $-5,73$ & 0,0000 & 0,5869 & 0,0008 \\
\hline $\begin{array}{l}\text { Cohesion through the } \\
\text { use of linking-words }\end{array}$ & 2,9643 & 3,3571 &,- 3929 & $-2,82$ & 0,0089 & 0,7424 & 0,0000 \\
\hline $\begin{array}{l}\text { Pertinence in relation } \\
\text { to cooperation }\end{array}$ & 3,0357 & 3,6071 &,- 5714 & $-3,15$ & 0,0040 & 0,7026 & 0,0000 \\
\hline $\begin{array}{l}\text { Clarity according to } \\
\text { cooperation }\end{array}$ & 3,1071 & 3,8571 &,- 7500 & $-4,97$ & 0,0000 & 0,7638 & 0,0000 \\
\hline Politeness & 3,3571 & 4,0714 &,- 7143 & $-7,07$ & 0,0000 & 0,8086 & 0,0000 \\
\hline
\end{tabular}

The pretest/posttest mean difference is negative in all thirteen variables, which means that final or posttest scores are higher than pretest or initial ones. This denotes an improvement or better performance on every single dependent variable. Statistical significance is found in eleven of thirteen variables at the .05 significance level.

Variable order according to best performance is: (1) Coherence referring to the logic of discourse (difference in means $=-1,1429 ; \mathrm{t}=-11,53$; $\mathrm{p}$-value $<0,0000$ ); (2) Discursive cohesion in semantic relationships (difference in means $=-0,9286 ; \mathrm{t}=-5,73$; $\mathrm{p}$-value $<0,0000$ ); (3) Lexico-semantic correction (difference in means $=-0,7857 ; \mathrm{t}=-4,99 ; \mathrm{p}$-value $<0,0000$ ); (4) Clarity according to cooperation (difference in means $=-0,7500 ; \mathrm{t}=-4,97 ; \mathrm{p}$-value $<0,0000$ ); (5) Politeness (difference in means $=-0,7143 ; \mathrm{t}=-7,07$; $\mathrm{p}$-value $<0,0000$ ); (6) Pertinence in relation to cooperation (difference in means $=-0,5714 ; \mathrm{t}=-3,15 ; \mathrm{p}$-value $<0,0040$ ); (7) Coherence referring to the construction of discourse (difference in means $=-0,5357 ; \mathrm{t}=$ 3,38; p-value <0,0022); (8) Adequacy of discourse of the interlocutor (difference in means = 
$-0,5000 ; \mathrm{t}=-3,00 ; \mathrm{p}$-value $<0,0057$ ); (9) Phonetic-phonological correction (difference in means $=-0,4643 ; \mathrm{t}=-3,30 ; \mathrm{p}$-value $<0,0027$ ); (10) Adequacy of discourse situation (difference in means $=-0,3929 ; \mathrm{t}=-3,31 ; \mathrm{p}$-value $<0,0027) ;(11)$ Cohesion through the use of linking words (difference in means $=-0,3929 ; \mathrm{t}=-2,82 ; \mathrm{p}$-value $<0,0089$ ).

Two dependent variables do not present statistically significant differences even though posttest scores are higher than those of the pretest: (1) Morphosyntactic correction (difference in means $=-0,2143 ; \mathrm{t}=-1,19 ; \mathrm{p}$-value $<0,2463)$; and (2) Adequacy of discourse object (difference in means $=-0,2143 ; \mathrm{t}=-1,80 ; \mathrm{p}$-value $<0,0830$ ). Adequacy of discourse object pretest/posttest differences verge on statistical significance, Morphosyntactic correction pretest/ posttest differences are insignificant.

Pearson's correlation coefficients for all variables are high (above 0,2500), and are all strongly significant at the 0.05 significance level (i.e.p-values are 0,0000 )

Detailed mean results by subcategory and thematic unit are given in Table 2 .

Table 2: Group means in each subcategory and thematic unit

\begin{tabular}{|l|l|c|c|c|c|c|c|c|c|c|c|}
\hline \multicolumn{2}{c}{ CATEGORIES \& } & Unit & Unit & Unit & Unit & Unit & Unit & Unit & Unit & Unit & Unit \\
\multicolumn{2}{c}{ SUBCATEGORIES } & 1 & $2-3$ & 4 & 5 & 6 & 7 & 8 & 9 & $10-11$ & $12-13$ \\
\hline \multirow{3}{*}{ Coherence } & Logic & 3,178 & 3,607 & 3,357 & 3,357 & 4,142 & 3,428 & 3,571 & 3,607 & 3,714 & 4,321 \\
\cline { 2 - 11 } & Construction & 3,250 & 2,892 & 2,571 & 2,857 & 3,535 & 3,071 & 3,000 & 3,107 & 3,464 & 3,785 \\
\hline \multirow{5}{*}{ Correction } & Morphosyntactic & 3,142 & 2,750 & 2,642 & 2,750 & 3,107 & 3,000 & 2,964 & 3,035 & 3,357 & 3,357 \\
\cline { 2 - 11 } & Lexico-semantic & 2,678 & 2,642 & 2,892 & 2,785 & 2,964 & 2,892 & 2,964 & 2,892 & 3,357 & 3,464 \\
\cline { 2 - 10 } & Phonetic-Phonological & 3,142 & 3,178 & 3,142 & 3,071 & 3,178 & 3,392 & 3,000 & 3,142 & 3,428 & 3,607 \\
\hline \multirow{3}{*}{ Cohesion } & Object & 3,892 & 3,821 & 3,571 & 3,535 & 3,785 & 3,821 & 3,250 & 3,642 & 3,678 & 4,107 \\
\cline { 2 - 10 } & Situation & 3,857 & 3,857 & 3,607 & 3,571 & 3,785 & 3,714 & 3,250 & 3,642 & 3,714 & 4,250 \\
\cline { 2 - 10 } & Interlocutor & 3,607 & 3,857 & 3,607 & 3,571 & 3,785 & 3,714 & 3,250 & 3,535 & 3,714 & 4,107 \\
\hline \multirow{2}{*}{ Cooperation } & Semantic relationships & 2,500 & 2,642 & 2,750 & 2,892 & 3,000 & 2,964 & 2,892 & 2,928 & 3,357 & 3,428 \\
\cline { 2 - 10 } & Use of linking words & 2,964 & 2,714 & 2,642 & 2,785 & 2,964 & 2,964 & 2,785 & 3,035 & 3,250 & 3,357 \\
\cline { 2 - 10 } & Pertinence & 3,035 & 3,535 & 3,178 & 3,035 & 3,285 & 3,071 & 3,071 & 3,357 & 3,392 & 3,607 \\
\hline Politeness & Plarity & 3,107 & 3,607 & 3,321 & 3,428 & 3,714 & 3,321 & 3,321 & 3,464 & 3,642 & 3,857 \\
\hline
\end{tabular}

Considering the mean information of the subcategory and thematic units that define the Didactic Intervention Program for the Development of Oral Discursive Competence from Table 2, we confirm that:

In the Logic of Discourse the initial mean score of the Program is 3,178 whereas the last mean score (units 12-13) is 4,321, the highest one achieved. This is a difference of $+1,143$, the highest in all the subcategories. However, though continuous from unit 8 on, this increase is not uniform, and presents two decreases in units 4 and 7 . There is a decrease of $-0,250$ between unit 2-3 and unit 4, and a decrease of -0,714 between unit 6 and unit 7 .

Similarly, the Construction of the discourse undergoes positive development from a 3,250 score in unit 1 to a 3,785 score in unit $12-13(+0,535)$. As in the previous case, the increase is not a linear one and decreases in units $2-3(-0,358), 4(-0,321), 7(-0,464)$ and 8 $(-0,071)$. The mean uninterruptedly increases from unit 9 on.

Variable Morphosyntactic correction evolves from a mean of 3,142 to 3,357; it undergoes an increase of $+0,215$. This progress along with that seen in Adequacy of discourse object makes these variables the ones with the lowest improvement. The pattern of results in this variable is similar to the one found in the previous variable: it decreases in units 2-3 $(-0,392)$, $4(-0,108), 7(-0,107)$ and $8(-0,036)$ and it uninterruptedly increases from unit 9 on. 
Concerning Lexico-semantic correction, it increases from one of the lowest initial scores $(2,678)$ to 3,464 at the end of the program. This increase turns into one of the most meaningful differences $(+0,786)$; only exceeded by the improvement in the Logic of discourse and Discursive Cohesion in semantic relationships. In this variable we also find that the mean decreases in units 2-3, 5 and 9. However, they are not very significant since between units 1 and 2-3 there is a difference of 0,036 , a difference of $-0,107$ between unit 4 and unit 5 , and a difference of $-0,072$ between unit 8 and unit 9 .

Concerning Phonetic-phonological correction there is an improvement of $+0,465$, from an initial score of 3,142 to a final one of 3,607. Decreases are found in this variable in units $4(-0,036), 5(-0,071)$ and $8(-0,392)$.

The Adequacy to discourse object increases from a 3,892 score to a 4,107 score, which is a difference of $+0,215$. Decreases are seen in thematic units $2-3(-0,071), 4(-0,250), 5$ $(-0,036)$ and $8(-0,571)$ and an uninterrupted increase is seen from units 9 through 12-13.

In the Adequacy to the situation of communication there is an increase of $+0,393$, from an initial score of 3,857 to a final score of 4,250 . This variable increases with no alteration from unit 9 , however, it presents decreases with respect to previous units in units $4(-0,250)$, $5(-0,036), 7(-0,071)$ and $8(-0,464)$.

The Adequacy of the interlocutor increases from 3,607 to 4,107 score, i.e., $+0,500$. Similar to the previous variable, there is a continuous increase from unit 9 on, but decreases are produced in units $4(-0,250), 5(-0,036), 7(-0,071)$ and $8(-0,464)$.

Improvement in the use of Semantic relationships is $+0,928$, the second highest increase after the Logic of the discourse. It progresses from an initial 2,500 score to a 3,428 score. There is a continuous increase from unit 9 on, and only in units 7 and 8 are there unimportant decreases with respect to their previous units, $-0,036$ and $-0,072$ respectively. It is the variable with the most regular progress.

Use of linking words improves in $+0,393$ (from 2,964 in unit 1 to 3,357 in 12-13). In its progress we find decreases in units $2-3(-0,250), 4(-0,072)$ and $8(-0,179)$, and an uninterrupted increase from unit 9 on.

The variable Pertinence goes from a 3,035 score in the first unit to a 3,607 score in the last one $(+0,572)$. There is a continuous increase from unit 8 and decreases in $4(-0,357), 5$ $(-0,143)$ and $7(-0,214)$ with respect to the preceding units.

In relation to Clarity, there is an increase of $+0,750$, between the first unit 3,107 and last unit 3,857 . The score improvement is continuous from unit 8 on and decreases in units 4 $(-0,286)$ and $7(-0,393)$.

Progress in Politeness is also positive in $+0,714$ (from 3,357 to 4,071). In this case the final increase takes place from unit 9 on (with the same mean score as number 8 ), and we find decreases in units $4(-0,214), 7(-0,036)$ and $9(-0,250)$ with respect to units 3,6 and 8 .

Table 3 presents the subcategory final mean scores in decreasing order. 
Table 3: Subcategory final mean scores in decreasing order

\begin{tabular}{|l|c|}
\hline \multicolumn{1}{|c|}{ SUBCATEGORIES } & MEAN \\
\hline Coherence referred to the logic of discourse & 4,321 \\
\hline Adequacy to discourse situation & 4,25 \\
\hline Adequacy to discourse object & 4,107 \\
\hline Adequacy of discourse of interlocutor & 4,107 \\
\hline Politeness & 4,071 \\
\hline Clarity in relation to cooperation & 3,857 \\
\hline Coherence referred to discourse construction & 3,785 \\
\hline Phonetic-phonological correction & 3,607 \\
\hline Pertinence depending on cooperation & 3,607 \\
\hline Lexical-semantic correction & 3,464 \\
\hline Discursive cohesion in semantic relationships & 3,428 \\
\hline Morph-syntactic correction & 3,357 \\
\hline Cohesion through use of linking words & 3,357 \\
\hline
\end{tabular}

\section{Analysis}

Concerning Coherence, there is a better pattern of results with Discourse logic than with Discourse construction. Both start with almost the same score $(+3,178$ and $+3,250)$; however, although they subsequently follow a quite parallel pattern, the second one remains below the first one $(+4,321$ and $+3,785)$.

In relation to Correction, although there are some divergences in its progress, the final scores of the three subcategories integrating this category are very close (Morphosyntactic, $+3,357$; Lexico-semantic, $+3,464$ and Phonetic-Phonological, $+3,607)$.

Progress in Adequacy becomes more evident due to the similarity of the scores of its three subcategories (Adequacy to discourse object, Adequacy to discourse situation and Adequacy of discourse of the interlocutor); in other words there is parallel progress all through the program and therefore a similar final pattern of results $(+4,107 ;+4,205$ and $+4,107)$. This final pattern of results closes the small distance found in Adequacy of interlocutor in the first unit, where it was slightly below Adequacy of object and Adequacy of situation $(+3,607$ versus $+3,892$ and $+3,857$ respectively).

Cohesion presents a difference in the first unit between Cohesion referring to semantic relations and Referring to use of linking words $(+2,500$ and $+2,964)$ which eventually and after following a parallel pattern of progress, almost disappears $(+3,428$ and $+3,357)$.

The pattern of results found in Cooperation is similar to that found in Cohesion. Pertinence in relation to cooperation and Clarity according to cooperation progress in a quite parallel way, though the former is always below the latter. The difference between these two subcategories is $+0,075$ in the first unit and it goes up to $+0,250$ at the end of the program.

Politeness progresses homogeneously from a value of $+3,357$ in the first unit to $+4,071$ in the last two. 
In any case, it is relevant to mention the fact that all categories and subcategories integrated in the Didactic Intervention Program for the Development of Oral Discursive Competence undergo positive progress.

\section{Conclusions}

Considering the experimental group's statistical pattern of results with respect to oral discursive competence before and after the application of the didactic intervention program, it can be concluded that:

1) Students following the Didactic Intervention Program for the Development of Oral Discursive Competence improve during such a program in all the subcategories it contains:

a) Improvement is statistically significant in the following categories and subcategories: Coherence, both referring to logic of discourse as well as its construction; Correction, in both lexico-semantic and phonetic-phonological; Adequacy, both to the situation of the discourse and to the interlocutor; discursive Cohesion, both in the semantic relationships as well as through the use of linking words; Pertinence; and Clarity in relation to cooperation as well as Politeness.

b) Concerning the subcategories Morphosyntactic correction and Adequacy to discourse object, improvement is not statistically significant.

2) At the end of the Didactic intervention program, learners have a better mastery of categories and subcategories related to language knowledge (Coherence) and to language social use (Adequacy and Politeness). However, this mastery is not as productive with categories and subcategories related to formal language knowledge (Morphosyntactic correction, Discursive cohesion in semantic relations or Cohesion through use of linking words).

3) With regard to improvement in subcategories during the Didactic Intervention Program for the Development of Oral Discursive Competence it can be concluded that:

a) The two subcategories where learners have experienced a major improvement during the Program are Coherence with reference to the logic of discourse $(+1,143)$ and Discursive cohesion in semantic relationships $(+0,928)$.

b) The two subcategories where learners have shown the smallest improvement during the Program are Morphosyntactic correction $(+0,215)$ and Adequacy to discourse object $(+0,215)$.

c) It is confirmed that no subcategory has a linear progress through all the Program's sessions except for Lexical-semantic correction whose decreases are not very significant.

d) Out of the thirteen Program units, an improvement decrease with respect to the previous unit is recognized in unit 4 (11 subcategories decrease), unit 7 (9 subcategories decrease) and unit 8 (8 subcategories decrease).

e) In unit 6 learners' progress increases in all subcategories. In addition, there is a linear progression from unit 9 up to the end of the Program in all thirteen subcategories. 
Throughout this paper, and as expected from every research process, we have found limitations. Considering object or methodology research aspects related to the theoretical frame and type of empirical study followed to verify the initial hypothesis, we would like to briefly mention the following aspects:

1) From the oral communication point of view, an academic year (such as in our case) turns out to be a relatively short period to observe discursive competence progress, which makes this observation a difficult task. Another difficulty related to oral language work refers to its ephemeral condition, which implies the use of technical means that do not always include the expected quality. Because of the two previous difficulties, program evaluation in the Language and Literature field is a complex task. Difficulty in evaluating oral language magnifies due to the interference of affective factors and the problem of efficient grading without interrupting the discourse.

Finally, another limitation refers to the lack of teachers' educational training to teach oral language in both primary and secondary education.

2) From the point of view of the methodology used, one needs to consider that most of the investigations carried out nowadays in the field of education have the double aim of improving the teaching/learning process and of making students benefit from their schooling as much as possible. Such investigations need to be carried out with rigorous scientific methods. However, since designs might be different, repercussions of conclusions need to be determined as clearly as possible in every case.

As previously stated, this investigation is founded on a quasi-experimental design due to lack of random sample selection. Such a design is the most commonly used during didactic interventions, and needs to be carried out on specific rooms and students.

\section{REFERENCES}

Bateson, G. et al. (1994). La nueva comunicación. Barcelona: Kairós.

Beaugrande, R. de, Dressler, W. (1981). Introducción a la lingüística del texto. Barcelona: Ariel.

Brown, P. and Levinson, S. (1994). Politeness. Some universals of language usage. Cambridge University Press.

Cassany, D., Luna, G. \& Sanz, G. (1994). Enseñar Lengua. Barcelona: Graó.

Coseriu, E. (1992). Competencia lingüística. Elementos de la teoría del hablar. Madrid: Gredos. Cronbach, L.J. (1987). Issues in planning evaluations, in R. Murphy \& H. Torrance (eds.). Evaluating Education: Issues and Methods. London, Harper.

Dendaluce Segurola, I. (1994). Diseños Cuasiexperimentales, in Víctor García Hoz et al. (eds.) Problemas Metodológicos de investigación en Educación Personalizada. Madrid: Rialp.

Dijk, T. van (1989). La ciencia del texto. Barcelona: Paidós.

Grice, P. (1969). Las intenciones y el significado del hablante, in L. Valdés (ed.) (1995). La búsqueda del significado. Lecturas de filosofía del lenguaje. Madrid: Tecnos-Universidad de Murcia.

Grice, P. (1975). Lógica y conversación, in L. Valdés (ed.) (1995). La búsqueda del significado. Lecturas de filosofía del lenguaje. Madrid: Tecnos-Universidad de Murcia. 
Halliday, M.A.K., \& Hassan, R. (1976). Cohesion in English. London: Longman.

Haverkate, H. (1994). La cortesía verbal. Estudio pragmalingüístico. Madrid: Gredos.

Leech, G. (1983). Principles of pragmatics. London: Longman.

Lomas, C. (1999). Cómo enseñar a hacer cosas con las palabras. (2 vol.). Barcelona: Paidós.

Lozano, J., Peña-Marín, C. \& Abril, G. (1993). Análisis del discurso. Hacia una semiótica de la interacción textual. Madrid: Cátedra.

Núñez, M. P. (2002). Un modelo didáctico para el desarrollo de la competencia discursiva oral. Lenguaje y Textos, 19, 161-199.

Sperber, D., \& Wilson, D. (1986). La relevancia. Comunicación y cognición. Madrid: Visor. 